some level with the military regime if they are to achieve their goals.

Yet it is important to ask whether the distorting lens of passion has come into play. The imminent threat to Myanmar's biodiversity is not in doubt, nor is the desire of Burmese conservationists for foreign assistance. It is also good to hear that some biologists working in Myanmar have sought the views of ordinary Burmese people.

But some statements do give cause for concern. Attempts to justify engaging with a government guilty of atrocities by arguing that other regimes are just as bad are not compelling. The suggestion that Burmese exiles have exaggerated the abuses in Myanmar is discomforting, as is the notion that conservation biologists need to use 'charm and guile' to convince suspicious politicians back in the United States that they are not abetting the Burmese junta.

These may just be poorly chosen words. But it is hard not to wonder, on hearing the stories of those working in Myanmar, whether some conservation biologists are prone to rush to the aid of threatened biota first, and to wrestle with the wider political and humanitarian implications only later. If that's the case, it is a dangerous tendency. As any psychologist will tell you, the human mind is adept at conjuring up post hoc justifications for a course of action that has already been decided.

We should also heed the lessons of history. Today it is widely accepted that effective conservation requires the involvement of local people, and should bring them tangible benefits. But the annals of conservation are littered with instances of people being seen as obstacles that must be removed to make way for parks and reserves. This isn't even limited to undemocratic countries: in the United States, decades ago, conservationists pursued projects such as the Shenandoah National Park in Virginia, whose creators portrayed local mountain farmers as backward and hounded them off their land.

Given this legacy, conservation biologists have a responsibility to ensure that their efforts do not conflict with local peoples' rights, or lend legitimacy to regimes that have dismal human-rights records. This doesn't mean that "Conservation biologists have a responsibility to ensure that their efforts do not conflict with local people's rights or lend legitimacy to regimes that have dismal human-rights records." they shouldn't work at all in countries such as Myanmar. But they should set out for their field sites with their eyes wide open, having researched the humanitarian issues and engaged with parties who may not share their view that conserving biodiversity is the overwhelming priority for the region in question. That will build more confidence that saving the rhino doesn't require unacceptable compromises on human rights.

\title{
Much whaling and gnashing of teeth
}

\section{The International Whaling Commission may be messy, but it's the only game in town.}

M arine biologists at this month's annual meeting of the International Whaling Commission (IWC) at Ulsan in South Korea will require considerable patience and fortitude. "It's like banging your head against the wall," complained one scientist there for the preliminary scientific-committee meeting.

The main bone of contention at this year's meeting is a proposal by Japan to double the scope of its 'research whaling' programme - its thinly disguised arrangement to continue some whaling despite a moratorium on commercial whaling that the IWC implemented in 1986 (see Nature 435, 550; 2005). The plan may get a sympathetic hearing at Ulsan because pro-whaling nations now seem to have a majority on the IWC for the first time (see page 861 ). This has come about because 23 new members - some with a dubious interest in whales, dead or alive - have joined the IWC in the past five years, taking its total membership to 62 . Whaling opponents whisper that Japan "goes shopping", as one of them puts it, for small, poor countries such as Kiribati and Tuvalu in the south Pacific to join the body in exchange for aid.

It is unlikely, however, that the new composition of the IWC will lead to radical changes in whaling rules, which would require a three-quarters majority. Japan's research programme was never actually approved by the body in the first place; Japan has sometimes chosen to brush the IWC's non-binding views on the matter aside.
"Resolutions adopted by the IWC against Japan's whale research programmes are political statements that have nothing to do with science," sniffed Joji Morishita, a spokesman for Japan's fisheries agency, in a statement issued during the meeting.

Opponents of whaling continue to regard Japan's research programme as an affront to conservation efforts, and Japan has been hard-pressed to come up with convincing, peer-reviewed articles supporting it. Now it says it needs an even larger programme to address the demands of the IWC's scientific committee. More sophisticated analysis requires a greater sample size - who can argue with that?

Given all this chicanery, one might be tempted to ask why researchers should bother to spend so many long days and nights in South Korea engaging in the IWC process.

But buffeted by criticism as it may be, the IWC continues to implement the international regime that stands in the way of unregulated whaling - and of the probable extinction of several whale species. Before the moratorium, Japan's yearly quota of minke whale in the Southern Hemisphere was 1,941 ; under its proposed research programme, it "The IWC continues
to implement the
international regime that
stands in the way of
unregulated whaling." would catch 935 .

And despite its grouching, Japan wants to be seen as a good international citizen; it is unlikely to pack up its marbles and go home. It will remain at the table, infuriating its opponents at times but basically conforming with an imperfect international process. Conservation biologists should do likewise, cajoling more friendly nations to sign on and grimly adhering to the only path that can, in its convoluted way, save the whales. 